\title{
INDO - CHINA TRADE: A NEW CENTRE PERIPHERY RELATIONSHIP
}

\author{
Dr. Vaibhav Agrawal \\ Assistant Professor, Department of Economics (Guest Faculty), S.S.Khanna Girls' Degree College, \\ University of Allahabad,
}

Article DOI: https://doi.org/10.36713/epra8488 DOI No: $10.36713 /$ epra8488

\begin{abstract}
Indo China trade names for last 3-4 years mainly because of three reasons one; China has become the robust trading partner of India outpacing USA, second; the balance of trade deficit of India is very high almost 60 Billion dollar, three; India and China are face to face on boundary issue and army skirmishes which has led to a boycott China slogan in India. But the issue do not end here. In fact China has become a manufacturing hub of all kind of industries in India. The inputs assembles spares as well as sophisticated machinery in India all Imported from China. In pandemic Covid-19 found that even dominant pharmaceutical companies of India are dependent on Chinese support. The whole consumer durable market of India is in fact only an assembly market. All parts of refrigerator, AC, cameras, microwave and what not are imported and then only assembly is done by Indian companies. Same is true for Electric gadgets, Telecommunication instruments, plastic industry and even handicrafts and handloom sector. Economics call it dependency of development. A Metropolis satellite like relationship in which India's economic development at present is been conditioned by China. In fact this is an extension of Prebisch singer Centre periphery model where in the International division of labour is such that some group of countries (periphery) output, raw material, agro and mineralbased product to while the other group of countries (Centre) add value and exports them back to periphery. This leads to exploitation of resources of periphery and analogous development of the developed countries. In this research paper the researcher is trying to analyse the Indochina trade through the lens of dependency theory.

KEYWORDS: Centre periphery relationship, manufacturing, exports, BOT, Indo China trade
\end{abstract}

India and China are two most populous countries of the world with more than $35 \%$ population but with less than $5 \%$ of land surface of the world. They are our neighbours but since long they have been disputing on geographical boundaries and had an open war in 1962 and more than 30 skirmish between soldiers during last twenty years. India blames China for its expansionist policies while China is annoyed on the issue of Dalai lama. In recent years China has been supporting Pakistan and Nepal on various issues of Afghanistan and Kashmir against India. Thus one can easily conclude that Indo- China political relations are far from satisfactory. On the other hand Indo-China trade relationship have grown so much so that today China is the largest trading partner of India. It's true that in ancient times India's trade with China flourished through silk route but in modern times Indo China trade was almost negligible since independence. The bilateral trade between India and China began in 1980's when India and China entered into a trade agreement which provided them the status of MFN (although China was not a full member of GATT). In 1991 Indian policy makers changed the policy of inward looking to open era policy of globalization. China had opted this policy with great controls since 1978. In 1992 India and China agreed to participate fully in enhancing bilateral trade. In 1994 double taxation agreement was signed by both. They also agreed to become a dialogue partner with ASEAN in 2003. This was the period when India had completed first generation reforms and began to liberalize. In 2003 Bangkok agreement was signed with both countries provided a list of commodities where trade performance would be provided. Both agreed to open setting route for trade. Now both countries are members of WTO so economic and trade relations between India and China are rising despite military insurgencies and political overtones. Following table shows the growth of foreign trade between India and China. 
Table -1: INDIA'S BALANCE OF TRADE FROM 1991-2021

\begin{tabular}{|c|c|c|c|}
\hline Year & $\begin{array}{c}\text { Goods } \\
\text { Export To } \\
\text { China( Us } \\
\text { Million \$) }\end{array}$ & $\begin{array}{c}\text { Goods Import } \\
\text { From } \\
\text { China(Us } \\
\text { Million \$) } \\
\end{array}$ & $\begin{array}{c}\text { Balance Of } \\
\text { Trade(Us } \\
\text { Million \$) }\end{array}$ \\
\hline 1991 & 48.3 & 21 & 27.3 \\
\hline 1992 & 157.8 & 140.8 & 17.0 \\
\hline 1993 & 279.1 & 299.4 & -20.30 \\
\hline 1994 & 254.2 & 757.3 & -503.10 \\
\hline 1995 & 331.7 & 810.1 & -478.40 \\
\hline 1996 & 614.8 & 756.5 & -141.70 \\
\hline 1997 & 718.1 & 1100 & -381.90 \\
\hline 1998 & 427 & 1100 & -673.00 \\
\hline 1999 & 542 & 1300 & -758.00 \\
\hline 2000 & 734.9 & 1500 & -765.10 \\
\hline 2001 & 922.5 & 1800 & -877.50 \\
\hline 2002 & 1500 & 2600 & -1100.00 \\
\hline 2003 & 2600 & 3600 & -1000.00 \\
\hline 2004 & 5615.88 & 7097.08 & -27981.49 \\
\hline 2005 & 6759.10 & 10808.05 & -46075.19 \\
\hline 2006 & 8287.48 & 17447.01 & -59341.43 \\
\hline 2007 & 9490.67 & 24580.76 & -15090.09 \\
\hline 2008 & 10090.32 & 31590.23 & -21499.91 \\
\hline 2009 & 10370.87 & 30610.76 & -20240.89 \\
\hline 2010 & 17440.97 & 41250.44 & -23809.47 \\
\hline 2011 & 16720.65 & 55480.66 & -38760.01 \\
\hline 2012 & 14730.34 & 54140.33 & -39409.99 \\
\hline 2013 & 16420.23 & 51640.77 & -35220.54 \\
\hline 2014 & 13430.22 & 58230.71 & -44800.49 \\
\hline 2015 & 9580.14 & 61600.34 & -52020.02 \\
\hline 2016 & 8920.65 & 60480.65 & -51560 \\
\hline 2017 & $13,333.53$ & $76,380.70$ & $-162,054.83$ \\
\hline 2018 & $16,752.20$ & $70,319.64$ & $-184,000.33$ \\
\hline 2019 & $16,612.75$ & $65,260.75$ & $-161,348.24$ \\
\hline 2020 & $21,187.15$ & $65,212.25$ & $-102,627.40$ \\
\hline 2021 & 4450.85 & $13,649.30$ & $-21,167.50$ \\
\hline
\end{tabular}

Table -2: INDIA'S BALANCE OF TRADE FROM 1991-2000

\begin{tabular}{|c|c|c|c|}
\hline Year & $\begin{array}{c}\text { Goods Export To } \\
\text { China ( Us Million \$) }\end{array}$ & $\begin{array}{c}\text { Goods Import From } \\
\text { China(Us Million \$) }\end{array}$ & Balance Of Trade(Us Million \$) \\
\hline 1991 & 48.3 & 21 & 27.3 \\
\hline 1992 & 157.8 & 140.8 & 17 \\
\hline 1993 & 279.1 & 299.4 & -20.3 \\
\hline 1994 & 254.2 & 757.3 & -503.1 \\
\hline 1995 & 331.7 & 810.1 & -478.4 \\
\hline 1996 & 614.8 & 756.5 & -141.7 \\
\hline 1997 & 718.1 & 1100 & -381.9 \\
\hline 1998 & 427 & 1100 & -673 \\
\hline 1999 & 542 & 1300 & -758 \\
\hline 2000 & 734.9 & 1500 & -765.1 \\
\hline CAGR & $\mathbf{0 . 3 1 2 8 8 9 3 0 8}$ & $\mathbf{0 . 5 3 2 4 5 3 1 1 6}$ & \\
\hline
\end{tabular}




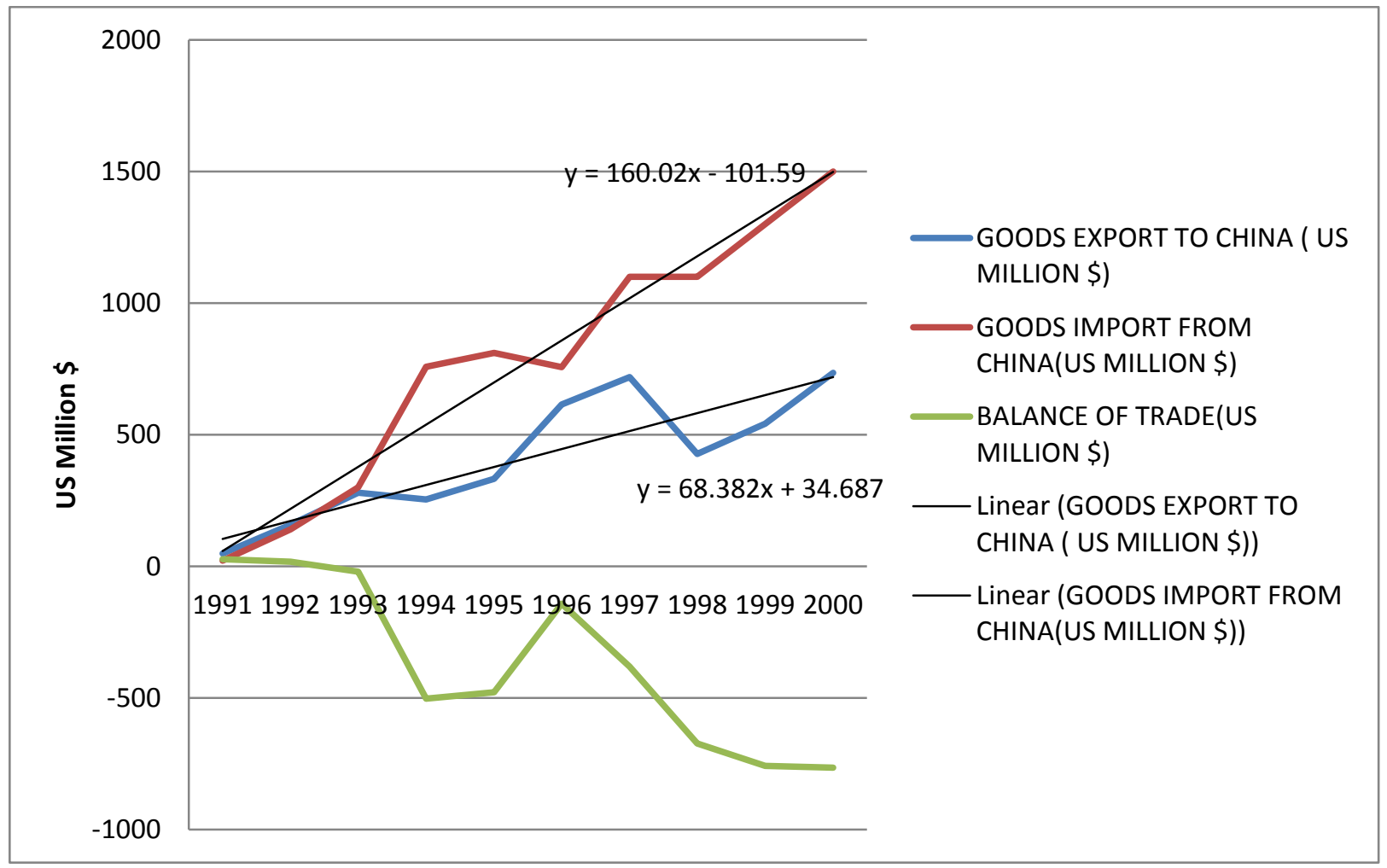

Fig -1: INDIA'S BALANCE OF TRADE FROM 1991-2000

Table -3: INDIA'S BALANCE OF TRADE FROM 2001-2010

\begin{tabular}{|c|c|c|c|}
\hline Year & $\begin{array}{c}\text { Goods Export To } \\
\text { China ( Us Million \$) }\end{array}$ & $\begin{array}{c}\text { Goods Import From } \\
\text { China(Us Million \$) }\end{array}$ & Balance Of Trade(Us Million \$) \\
\hline 2001 & 922.5 & 1800 & -877.5 \\
\hline 2002 & 1500 & 2600 & -1100 \\
\hline 2003 & 2600 & 3600 & -1000 \\
\hline 2004 & 5615.88 & 7097.08 & -27981.49 \\
\hline 2005 & 6759.1 & 10808.05 & -46075.19 \\
\hline 2006 & 8287.48 & 17447.01 & -59341.43 \\
\hline 2007 & 9490.67 & 24580.76 & -15090.09 \\
\hline 2008 & 10090.32 & 31590.23 & -21499.91 \\
\hline 2009 & 10370.87 & 30610.76 & -20240.89 \\
\hline 2010 & 17440.97 & 41250.44 & -23809.47 \\
\hline CAGR & $\mathbf{0 . 3 4 1 7 0 8 0 0 4}$ & $\mathbf{0 . 3 6 7 7 7 7 9 8 1}$ & \\
\hline
\end{tabular}




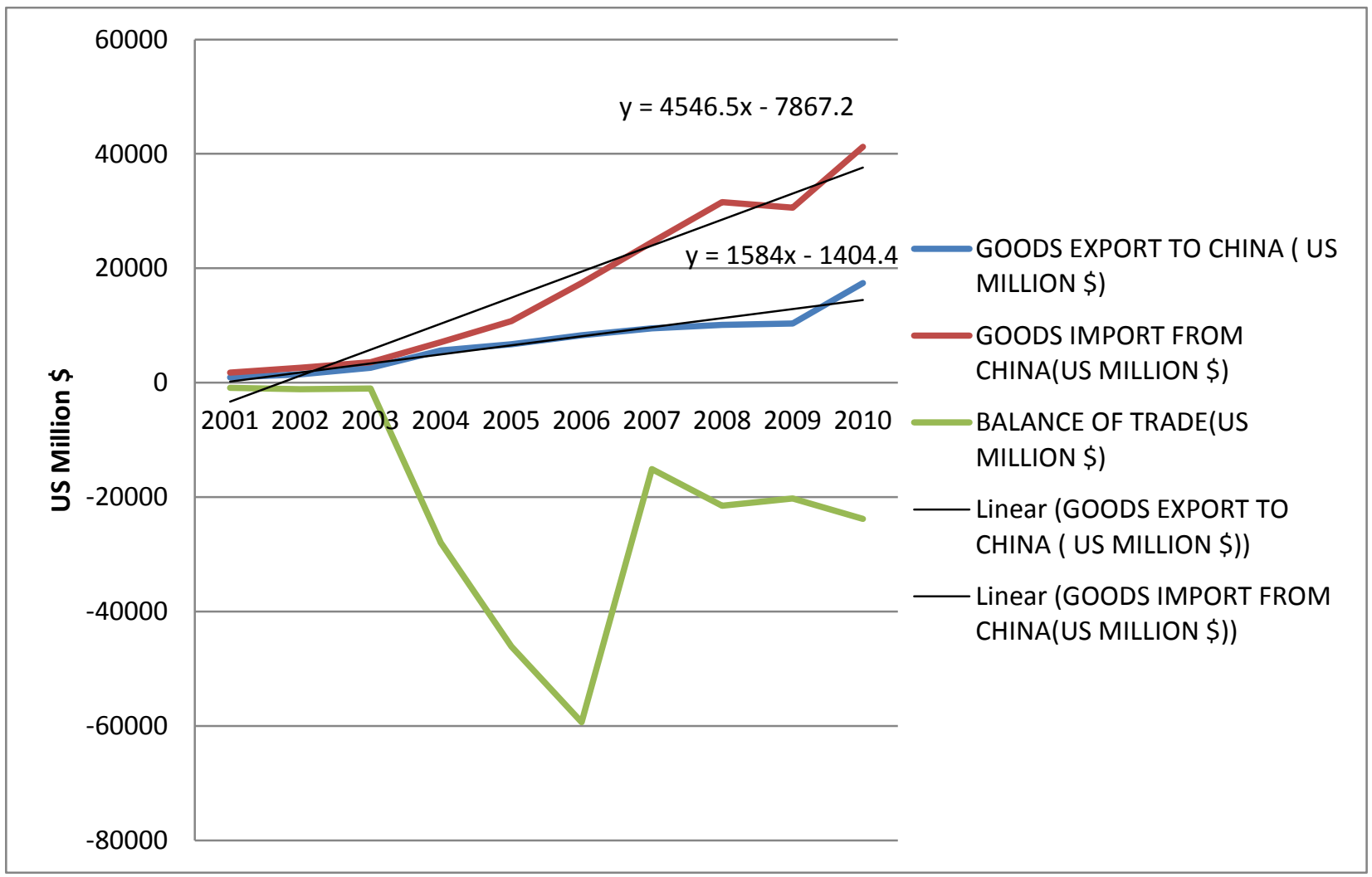

Fig -2: INDIA'S BALANCE OF TRADE FROM 2001-2010

Table -4: INDIA'S BALANCE OF TRADE FROM 2011-2021

\begin{tabular}{|c|c|c|c|}
\hline Year & $\begin{array}{c}\text { Goods Export To } \\
\text { China ( Us Million \$) }\end{array}$ & $\begin{array}{c}\text { Goods Import From } \\
\text { China(Us Million \$) }\end{array}$ & Balance Of Trade(Us Million \$) \\
\hline 2011 & 16720.65 & 55480.66 & -38760.01 \\
\hline 2012 & 14730.34 & 54140.33 & -39409.99 \\
\hline 2013 & 16420.23 & 51640.77 & -35220.54 \\
\hline 2014 & 13430.22 & 58230.71 & -44800.49 \\
\hline 2015 & 9580.14 & 61600.34 & -52020.02 \\
\hline 2016 & 8920.65 & 60480.65 & -51560 \\
\hline 2017 & $13,333.53$ & $76,380.70$ & $-1,62,054.83$ \\
\hline 2018 & $16,752.20$ & $70,319.64$ & $-1,84,000.33$ \\
\hline 2019 & $16,612.75$ & $65,260.75$ & $-1,61,348.24$ \\
\hline 2020 & $21,187.15$ & $65,212.25$ & $-1,02,627.40$ \\
\hline 2021 & 4450.85 & $13,649.30$ & $-21,167.50$ \\
\hline CAGR & $\mathbf{0 . 0 2 3 9 5 7 5 1 7}$ & $\mathbf{0 . 0 1 6 2 9 2 5 8 4}$ & \\
\hline
\end{tabular}




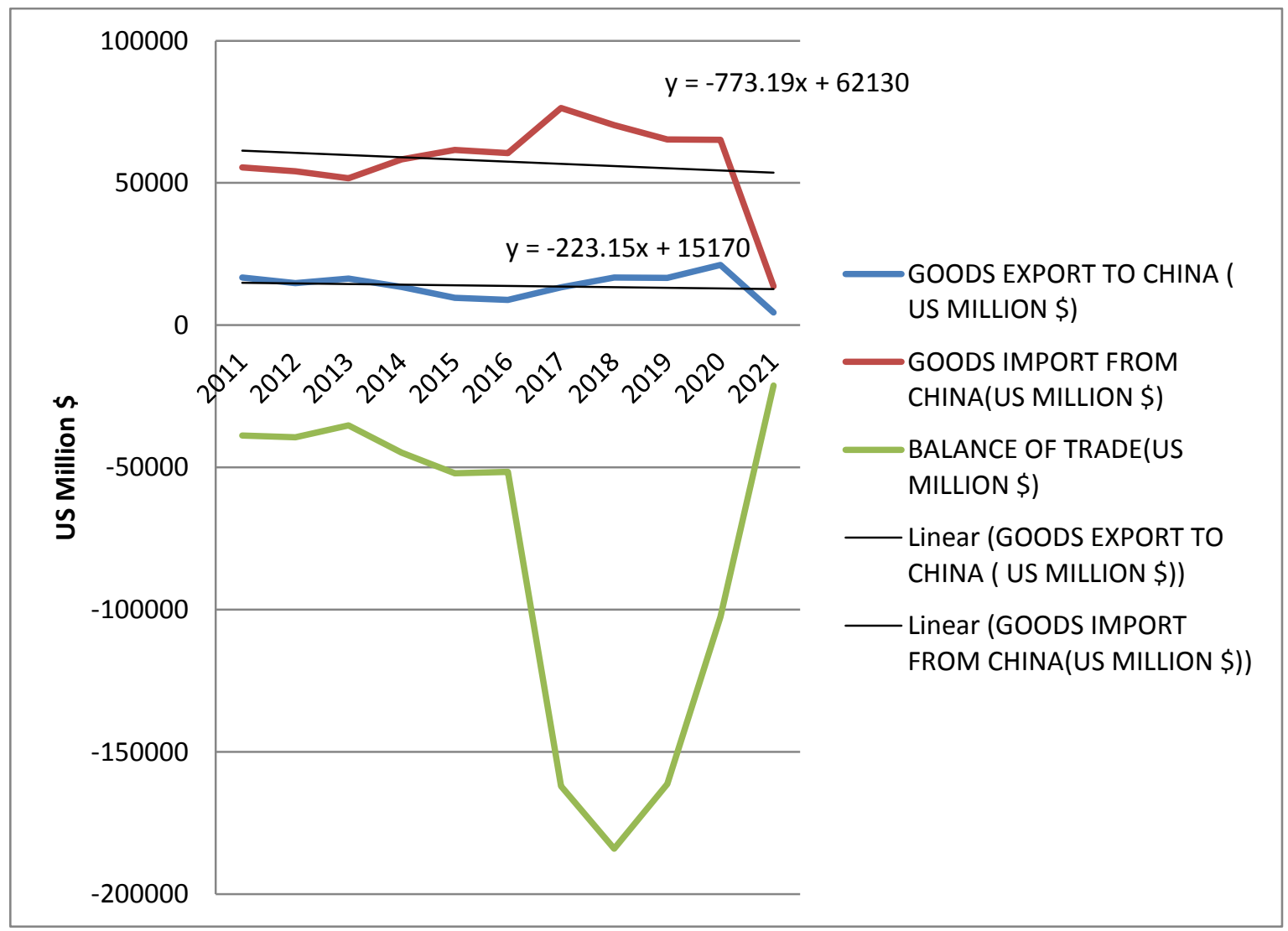

Fig -3: INDIA'S BALANCE OF TRADE FROM 2011-2021

A cursory glance on the above tables would be enough to demonstrate following facts-

(A) India- china trade was negligible in 1991 when India changed its policy regime from inward looking to globalization.

(B) Trade grew between 1991 to 2002 very rapidly but it seems high because of low base.

(C) Trade since 2003 has grown more than five times by 2020 .

(D) Trade is tilted towards China as India's balance of trade which was less than $\$ 1$ billion in 2000 has gone up to $\$ 40$ billion in 2019 i.e. 40 times.It must be remembered that China enjoys favourable balance of trade with almost all countries of the world.

(E) Since 2018 India has succeeded in reducing balance of trade deficit although marginally.

after a brief look at the data no one can deny China's dominance against India in trade. But the greater cause of worry for India China trade is different. The problem at hand can visualized by following two tables. The trade deficit has started growing since 2004 very rapidly. This was the period when India's GDP was growing at a very rapid speed (around 7\% to $9 \%$ ) per annum. This growth momentum was sustained on import growth of manufactured goods. In this period India's growth was service centric and in most manufacturing units India was only content with assemblies. Thus high growth was also called jobless growth which lead to India formulating plan of inclusive growth even after 2008 global recession in which only some countries including India and China posted positive growth India's import from China were rising rapidly because rising incomes in India generated a demand of consumer durables which in fact led to demand of Chinese goods as they were cheaper and attractive (although the same cannot be said about their durability and quality). 
Table 5: India's top Import items from China (\% of total imports)

\begin{tabular}{|c|c|}
\hline $\begin{array}{c}\text { India's top Import items from } \\
\text { China }\end{array}$ & $\%$ of total imports) \\
\hline $\begin{array}{lr}\text { 1) } & \text { Electrical } \\
\text { equipment, } & \text { machinery, } \\
\text { recorders, televisions }\end{array}$ & 34.5 \\
\hline 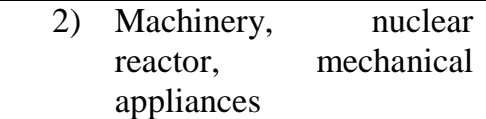 & 17.7 \\
\hline 3) Organic chemical & 9.3 \\
\hline 4) plastics and articles & 3.0 \\
\hline 5) Ships, floating structure & 2.9 \\
\hline 6) Iron and steel & 2.7 \\
\hline 7) $\quad$ Fertiliser & 2.5 \\
\hline 8) Articles of iron and steel & 2.0 \\
\hline Total & $75 \%$ \\
\hline
\end{tabular}

Table 6 : India's top Export items to China (\% of total exports)

\begin{tabular}{|l|c|}
\hline \multicolumn{1}{|c|}{ India's Top Exports } & \% of total Exports \\
\hline \multicolumn{1}{|c|}{ 1) Cotton } & 14 \\
\hline $\begin{array}{l}\text { 3)Mineral Fuels, Mineral } \\
\text { Oils }\end{array}$ & 13 \\
\hline 4) Copper and its articles & 8.8 \\
\hline 5) Salt, Sulphur, Lime Cement & 7.2 \\
\hline $\begin{array}{l}\text { 6) Machinery, Mechanical } \\
\text { Appliances, Nuclear Reactor }\end{array}$ & 7.2 \\
\hline 7) Electrical & 5.2 \\
\hline 8) Animal and vegetables fat & 4.4 \\
\hline 9) Plastic and Articles & 3.0 \\
\hline Total & 3.0 \\
\hline
\end{tabular}

A cursory glance of the table would suggest that there are three important groups of (1) machinery , mechanical appliance, nuclear reactor (2) plastic and articles and (3) electrical machinery in which intra industry trade is taking place that is both countries are exporting as well as importing these commodities grow each other but import of china are $1 / 20$ of its exports even in these areas while in other China's exporting finished goods and India has become a supplier of raw material be it cotton, ores, steel, mineral oil and fuels, salt, sulphur, animal fats (table2) etc while china's exports are mainly of finished goods.(table1) This is like Centre periphery relationships as developed by Raul Prebisch and Hans singer. Today in almost all the field of spare parts serving in India like durable consumer goods (A.C., T.V., fridge to small electrical appliances ) all big companies (L.G., Samsung, Sony) import all components and assemble (Make in India) and sell the finished good to consumers. Even in medicines $75 \%$ input are supplied by China both for infrastructure (ventilators, oxygen cylinders) as well as raw materials India is dependent on Chinese goods. In fact when China opened its economy to the world it had created large surplus of manufacturing goods. It developed an economy based on manufacturing all kind of goods (consumer and investment). It started producing textiles, machines, plastics as well as high sophisticated technology goods as atomic reactor and what not. The method was simple and clear. It utilized its manpower to research the production as well as consumption pattern of the world and created simple appropriate technology to meet such demand. A simple but powerful example is that most idols of Hindu Gods like saraswati, Ganesh and Laxmi were produced and exported by China to India while these Gods and Godesses are not worshipped in China. In fact Chinese researched as to what is demanded in different parts of the world started producing and exporting unlike India and others as well want to export whatever is surplus in the country. They simply started producing for exports. It also began to skill people in different areas. It enhanced productivity in every field and with lower wages reduced the cost of production. Moreover it always pegged the value of currency much lower to its actual value which did help in competing the other 
exporters and mostly outcompeted them. On the other hand India's development was service centric. Moreover another problem in relation to Indo Chinese trade is that still India is exporting raw material be it cotton, ores, ash, mineral fuels, salt , sulphur, lime or similar items in which china adds value and exports not only to India but to the world. This kind of trade is explained in dependency theory where the international division of labour allows the dominant country to exploit the natural sources of dominated country. Therefore if any country wants to become a developed country and also enhance its growth with employment it has to turn in to a manufacturing country as well just like China which has specialized in manufacturing but also in service sector where its not a large importer. Today each country needs to adopt a policy that it exports capital goods as well as services and is also an importer. Its neither rational nor desirable to be dependent on other countries for such large number of goods as is the case of India. There is no harm if Indian economy has the dominant service sector unlike China which is dominant in manufacturing and industries but the real problem is that employment elasticity in service sector is far less than in manufacturing and industry and this unemployment is a very big issue of India.

Moreover in this context if one looks at manufacturing sector of India which contributes $15 \%$ of GDP (almost stagnant in $21^{\text {st }}$ century) employs only $2 \%$ of the total population and imports another $15 \%$ to $18 \%$ of manufactures from China which could enhance employment in India by another $7 \%$. The total unemployment in India is around 9\% if we do not export our jobs to China our employment position could certainly be very satisfactory. The question is whether India's strategy of having a service centric growth a mistake? Or India can now develop its manufacturing industry by adopting suitable strategy.

\section{CONCLUSION}

There is nothing wrong in India's service sector growth strategy but the problem that is basic to India is that it has large population and at this point of time it is also on the right size of age pyramid. The average age of India is 26 years and by 2030 it would be around 29. But the population dividend can only be derived if India can provide employment at least at natural rate. For this the manufacturing sector must grow. Government had started various programmes but with no great success but the pandemic has given India a new ray of hope. Now Indian companies know fully well that their production and export can be arrested if they keep on depending on foreign inputs, spares and assemblies. The government should also thinks of unconventional monetary policy tools of extended lending at marginal rates to start ups and venture capital. The Indo china trade deficit in recent years has declines but not because India's exports have increased but because of great public sentiments. Indian consumers have reduced import of consumer items especially in those which are used in festivals like rakhi, Ganesh Laxmi statutes. Lighting, sprinklers and crackers but the same is not true for Indian industry and businesses. The whole world is looking at an alternatives to China in manufactures. Thus this is right time to bring out the innate leadership qualities of Indian Entrepreneurs to provide a viable alternative to Chinese goods not only for India but also for the whole world.

\section{REFERENCES}

1. Singh, Swaran. 2005. "China-India Bilateral Trade: Strong Fundamentals Bright Future." China Perspectives

2. Mohanty, S. K. 2014. India-China Bilateral Trade Relationship. New Delhi: Research and Information System for Developing Countries.

3. PHD Research Bureau. 2018. "India-China Trade Relationship: The Trade Giants of the Past, Present and the Future." PHD Chamber of Commerce and Industry.

4. https://doi.org/10.4000/chinaperspectives.2853. Primary Statistics

5. www.trademap.org

6. www.tradingeconomics.org

7. Press Information Bureau, Government of India

8. www.uncomtrade.ac.in

9. Ministry of Commerce and Industry, Department of Commerce, Government of India.

10. Economic Survey, Ministry of Finance, Department of Economic Affairs, Government of India. 